\title{
TECTONOSTRATIGRAPHIC TERRANE ANALYSIS ON NEOPROTEROZOIC TIMES: THE CASE STUDY OF ARAXÁ SYNFORM, MINAS GERAIS STATE, BRAZIL: IMPLICATIONS TO THE FINAL COLLAGE OF THE GONDWANALAND.
}

\section{HILDOR JOSÉ SEER ${ }^{1}$ AND MARCEL AUGUSTE DARDENNE ${ }^{2}$}

\begin{abstract}
The Araxá Synform is a regional fold with gently WNW plunging. The outcrops of the Araxá, Ibiá and Canastra Groups occur at their limbs. The region is the type locality of these units. These Groups belong to the Brasilia Fold Belt, a Neoproterozoic tectonic unit evolved at the western margin of the São Francisco-Congo Craton. Geological mapping, structural analysis, whole rock geochemistry, mineral chemistry, petrography and geochronology are the main tools to understand the tectonic evolution of these geological units. In this paper we apply tectonostratigraphic terrane analysis to the solution of stratigraphic problems in the Brasília Belt and Gondwanaland collage.
\end{abstract}

Keywords: Brasília Belt, Neoproterozoic, Brasiliano orogeny, Tectonic Evolution, Structural Geology

INTRODUCTION All geological information is necessary to understand the history of an orogenic belt, basically it comprises the integration of stratigraphic data with structural geology. The stratigraphic data provide information about paleogeography and ages of the geological units of an orogenic belt. The structural data describe the configuration of these units. To Howell (1993) an orogenic belt is essentially a puzzle, composed by a collection of crustal pieces. To reconstitute the sequence of events that give origin to an orogenic belt, we must identify the fundamental pieces that compose the puzzle. These pieces are defined as tectonostratigraphic terranes: "a faultbounded package of rock with a distinct stratigraphy that characterizes a particular geologic setting" (Howell 1993). As a consequence, a tectonostratigraphic terrane has no genetic relationships with its neighboring terranes. In the Araxá Synform, southern Brasilia Fold Belt, Minas Gerais State, Brazil (Fig. 1), we can apply the tectonostratigraphic terrane methodology to pre-Cambrian rocks (Seer 1999). This approach is different from that of earlier authors ( Barbosa et al. 1970, Paulsen et al. 1974, Ferrari 1989) who believed that distinct stratigraphic units may represent transitions or facies from one another, a fixist tectonic conception. A high mobility of the different geologic units without apparent genetic links, and originated by allocthonous processes from distinct geographic regions, is assumed in this paper. Geological mapping, structural analysis, petrography, whole rock geochemistry, mineral chemistry and geochronology were the main methodological procedures used to support such conclusions.

TECTONOSTRATIGRAPHY The Araxá Synform (Simões and Navarro 1996) is a regional fold, with WNW trending limbs, dipping NNE and SSW and with gently plunging hinges to WNW (Fig. 1). The outcrops of Araxá, Ibiá and Canastra Groups (Barbosa et al. 1970) occur at their limbs. The region represents the type locality for these geologic units.

Araxá, Ibiá and Canastra Groups are ordered in three tectonic thrust sheets, delimited by gently dipping and subvertical shear zones (Fig. 2).

The lower thrust sheet (Canastra Group) is a psamo-pelitic metasedimentary sequence, metamorphosed at greenschist facies (chlorite and garnet zones). It represents sedimentation on a marine platform environment and apparently constitutes a regressive marine cycle with predominant quartzites at the stratigraphic top. Their $\varepsilon_{\text {nat }}$ $=-12,77($ Brod 1999) and Sm-Nd model age of 2,2 Ga. indicate high crustal residence time and provenance from ancient source regions. This geologic unit was overthrusted the Bambuí Group, an autochthonous sedimentary cover deposited on the São Francisco Craton (Fig. 1).

The intermediate thrust sheet (Ibiá Group) is a pelitic metasedimentary sequence arranged as fine grain rhythmites. Their $\mathrm{Sm}-\mathrm{Nd}$ model ages are between 1,1 and $1,3 \mathrm{Ga}$. and they are metamorphosed to the chlorite zone of greenschist facies. Thus, they are short time crustal residence sediments, which is strengthened by feldspar abundance, especially plagioclase. Geochemically, these sediments are similar to graywackes from Oceanic Island Arcs (OIA) (Fig. 3). Their origin is linked to the erosional processes of neoproterozoic magmatic arcs (western Goiás State magmatic arcs) and they were possibly deposited through distal turbiditic currents.
The upper thrust sheet (Araxá Group) comprises a dominantly metamafic sequence (fine and coarse amphibolites, with rare ultramafic rocks) which is transitional to pelitic metasedimentary rocks, both metamorphosed under amphibolite facies conditions and intruded by granitoid rocks. The amphibolites represent gabbroic and basaltic protoliths. The basalts are high $\mathrm{FeO}$ tholeiites with REE signatures that resemble E-MORB (Figs. 4 and 5). Therefore, they could represent an oceanic crust evolved from a mixture of asthenospheric and lithospheric sources. The metasedimentary rocks could represent marine deep-water sedimentation associated with chert layers (fine orthoquartzites). They have Sm-Nd model age of 1,9 Ga., and $\varepsilon_{\mathrm{NdT}}=$ $-10,21$. Thus, their crustal residence time was longer than that of the Ibiá Group and shorther than the Canastra Group. In other places of Brasilia Belt, the metasediments of Araxá Group yield bimodal Sm-Nd model ages, with values of 1,9 and 1,3 Ga. (Pimentel et al. 1999b).

The granitic bodies are mainly two-mica leucogranites, peraluminous, with geochemistry and mineralogical signatures (Fig. 6) compatible with their origin in a collisional environment, and they contain xenoliths of the surrounding rocks. Their emplacement occurred through subhorizontal shear zones (thrust faults). All these features imply that their genesis is similar to that of two-mica peraluminous granitoids from another collisional belts (Barbarin 1996).

Therefore, the three thrust sheets of Araxá Synform may be described as tectonostratigraphic terranes, with distinct characteristics, representing specific geologic environments, originated at different geographic positions: a fragment of passive continental margin (Canastra Terrane), a fragment of the sedimentary portion of a magmatic arc (Ibiá Terrane), and a fragment of ocean basin intruded by collisional granites (Araxá Terrane).

TECTONIC EVOLUTION The deformational and metamorphic history of the Araxá Synform can be described through a succession of events, whose PTt path points to a geological process varying from deep to upper crustal levels (Fig. 7). The main metamorphism ( $\left.\mathbf{M}_{1}\right)$, dated $630 \mathrm{Ma}$ (Sm-Nd mineral isochrons), characteristically of the Barrovian type, is recorded in all thrust sheets. During this event, a $D_{1}$ deformational phase was developed associated with coarse $S_{1}$ schistosity of uncertain origin. A retrometamorphic RM $\mathrm{RM}_{1}$ event, without deformational imprint, followed the first event, and was recorded only in the lower and upper thrust sheets. The following event, $M_{2} / D_{2}$, can be divided into an early stage $\left(D_{2} p\right)$, and a later stage $\left(D_{2} t\right)$. Both developed in a collisional tectonic environment, with gently dipping shear zones that promote the collage of the thrust sheets, in retrograde greenschist-facies metamorphic conditions. During its initial stages, $\mathrm{D}_{2} \mathrm{p}$ was accompanied by granitic intrusions. Kinematic criteria indicate that these thrust sheets were transported from southwest to northeast. A $\mathrm{D}_{2} \mathrm{t}$ deformation began, apparently as a continuity of $\mathrm{D}_{2} \mathrm{p}$, though with a SE tectonic transport, accompanied by a SW-NE secondary compressional field. This deformation is found in the most outcrops and represents the main deformational event in the region. It was responsible for the construction of the Araxá Synform. The final event, $\mathrm{M}_{3} / \mathrm{D}_{3}$, was responsible for the development of wrench sinistral shear zones at lower greenschist-facies metamorphic conditions. Their stress field distribution is similar to that of $\mathrm{D}_{2} \mathrm{t}$ event, but their deformation took place at higher crustal levels. 

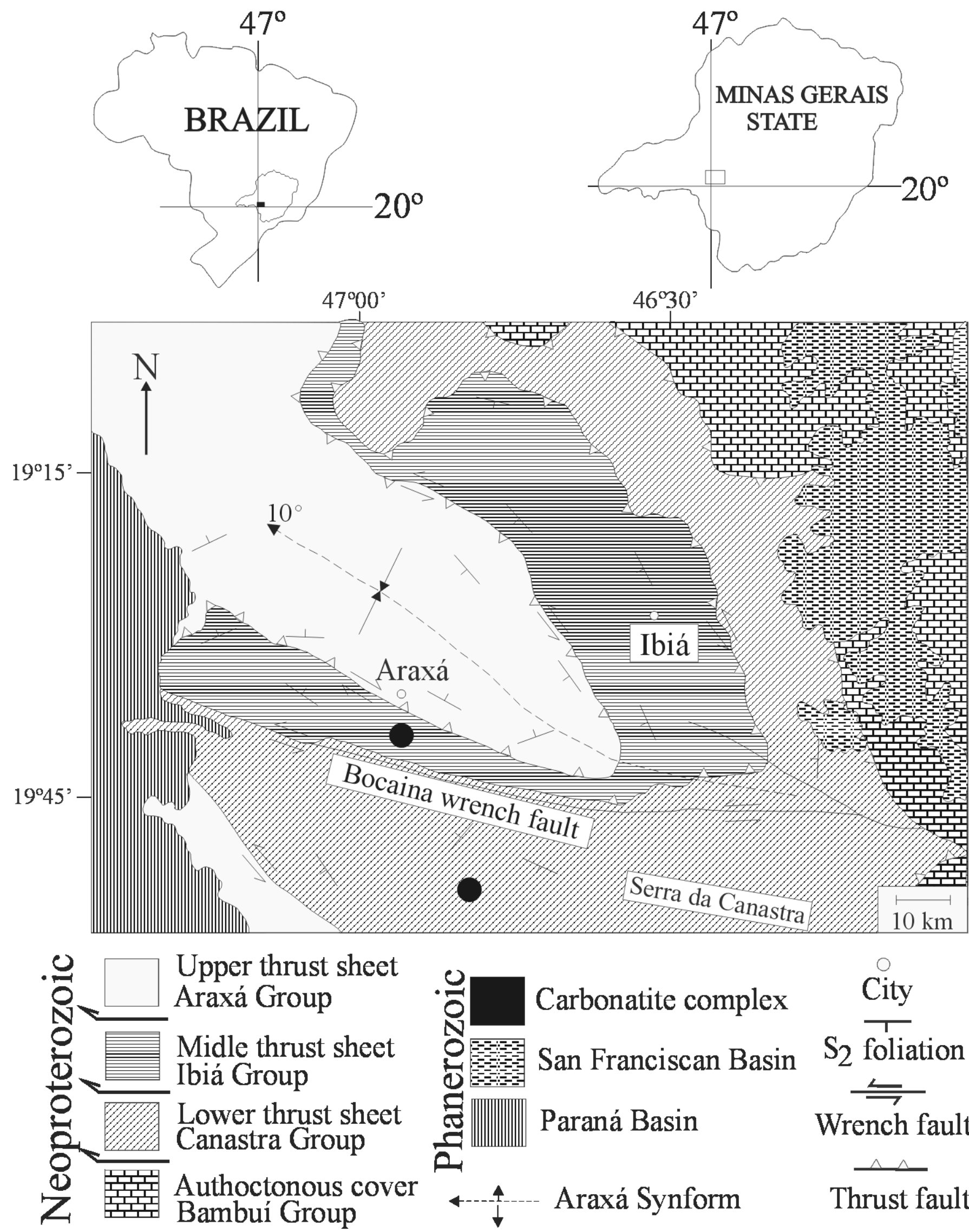

City

$\mathrm{S}_{2}$ foliation

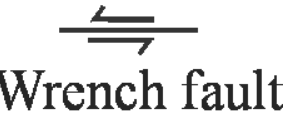

Thrust fault 


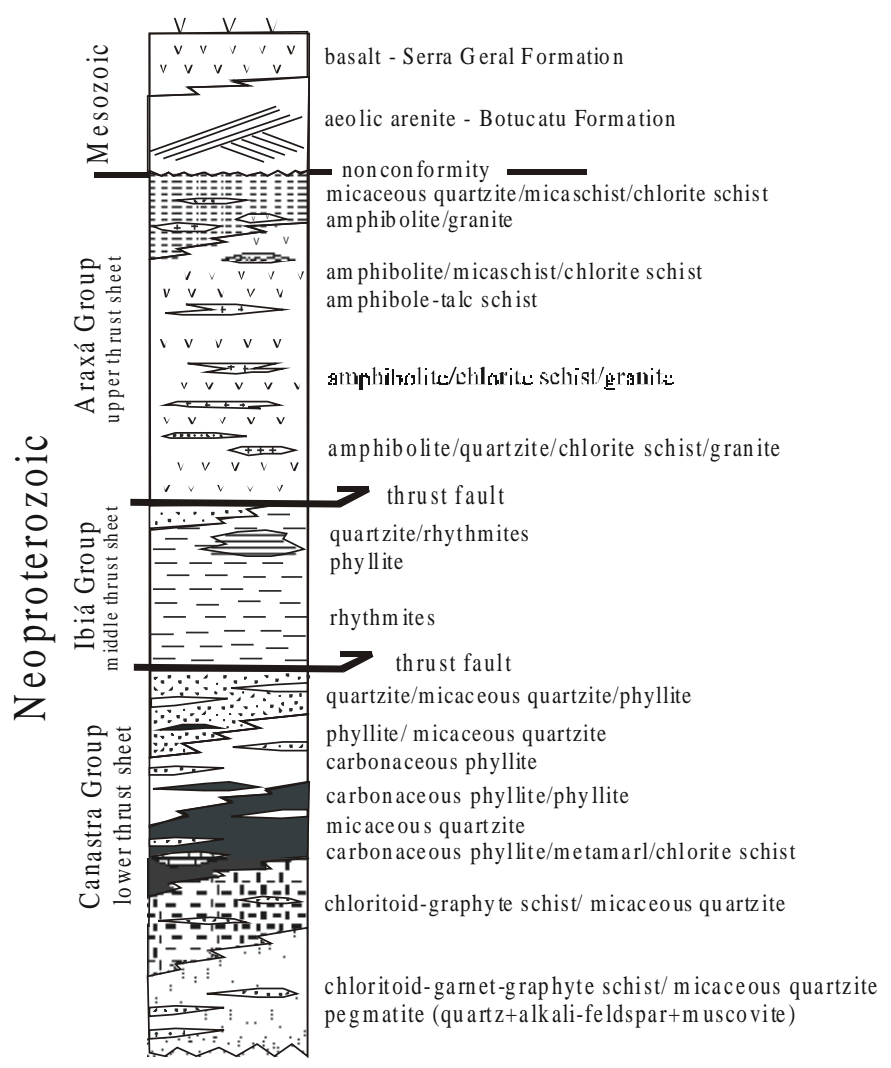

Figure 2 - Tectonostratigraphy of the Araxá Synform (Seer 1999).
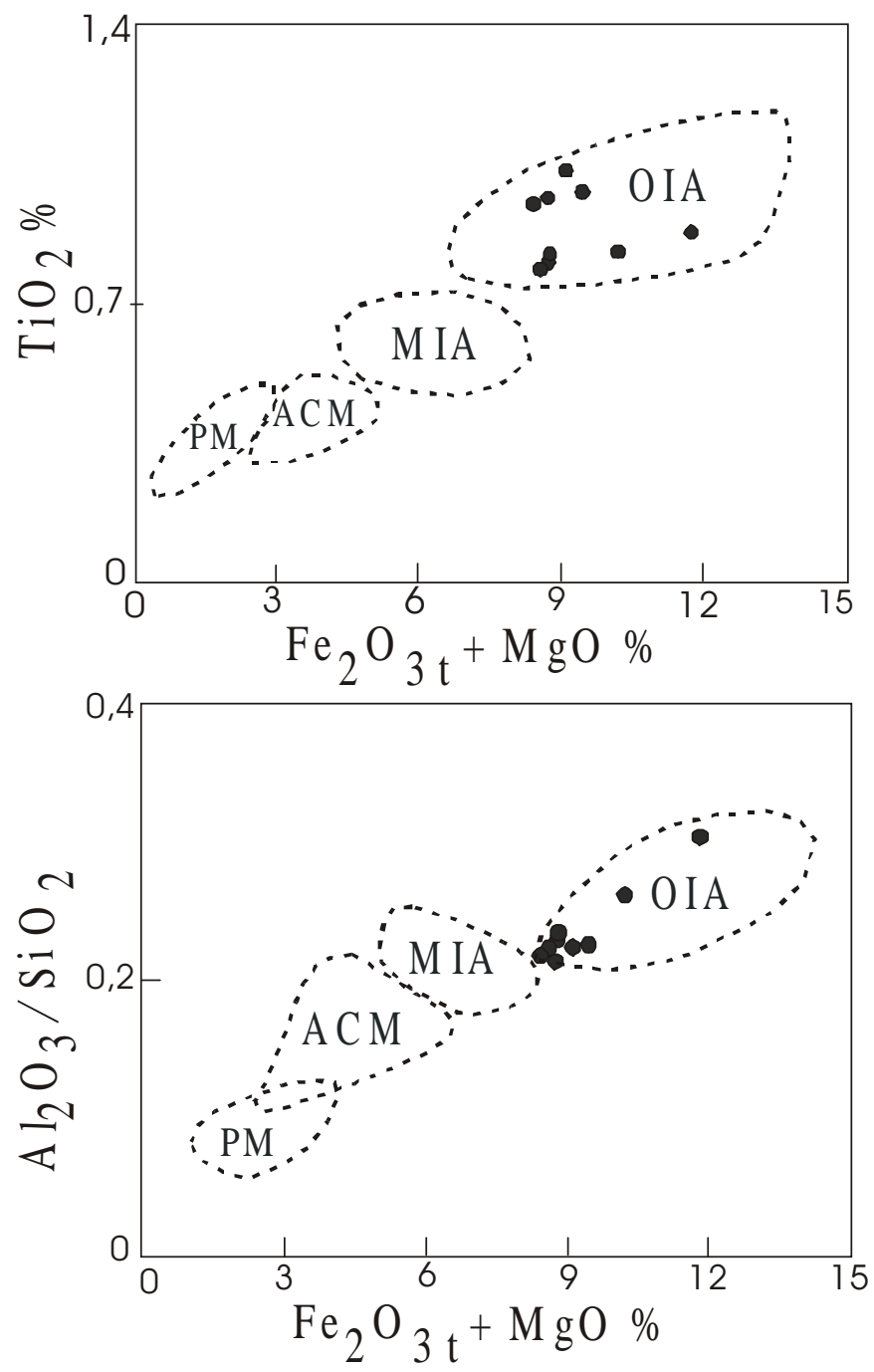

Figure 3 - Discriminant diagrams for the Ibiá Group metasediments (black points). Dashed fields represent graywacke compositions from Oceanic Island Arcs (OIA), Mature Island Arcs (MIA), Active Continental margins (ACM) and Passive Margins (PM) (data of the fields after Bhatia 1983).

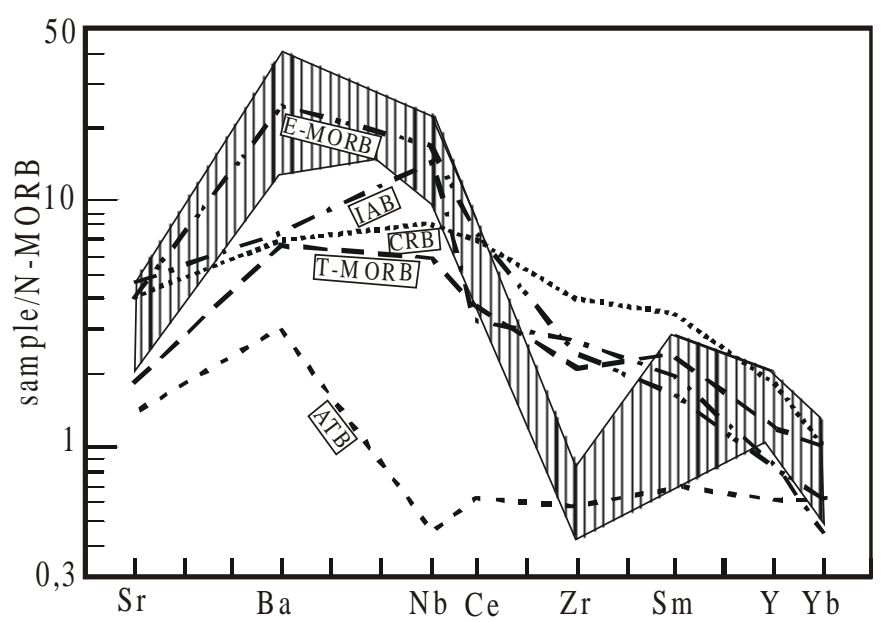

Figure 5 - Trace element patterns of the Araxá Group amphibolites (shaded area), compared with Transitional Mid-Ocean Ridge Basalts (T-MORB), Continental Rift Basalts (CRB), Island Arc Basalts (IAB), Arc Tholeiitic Basalts (ATB) and Enriched Mid-Ocean Ridge Basalts (E-MORB) (after Condie 1989).

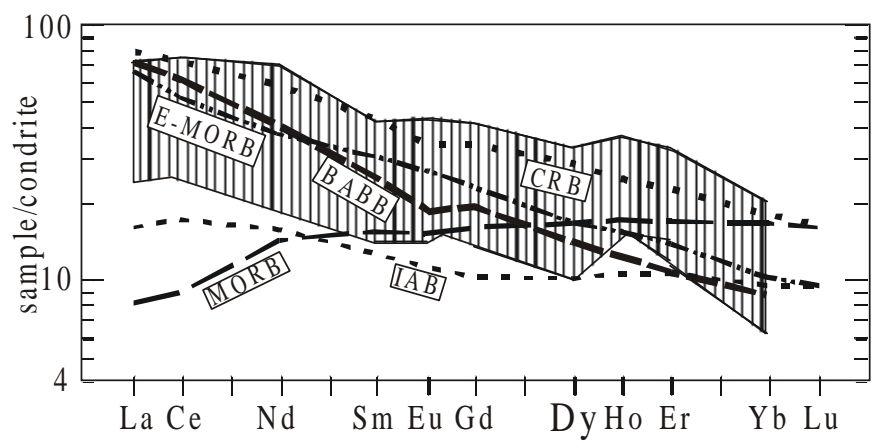

Figure 4 - Rare Earth Elements compositions of the Araxá Group amphibolites (shaded area) compared with Continental Rift Basalts (CRB), Island Arc Basalts (IAB), Mid-Ocean Ridge Basalts (MORB) (after Condie 1989), Backarc Basin Basalts (BABB) (after Price et al. 1990) and Enriched Mid-Ocean Ridge Basalts (E-MORB) (after Henderson 1984). 


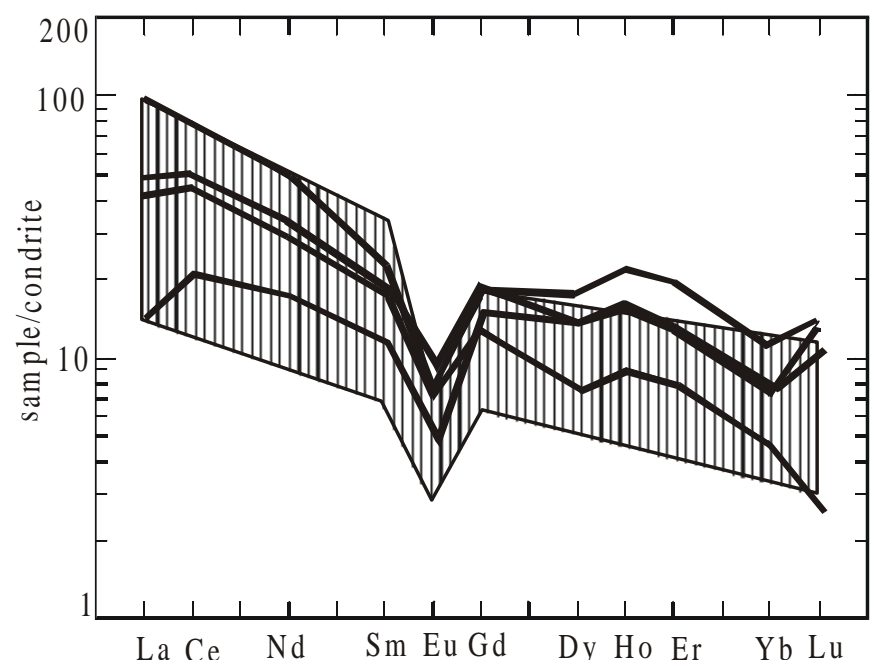

Figure 6 - Rare Earth Element patterns of the Araxá granites (black continuos lines). Shaded area represents composition of Hercinian and Himalayan collisional granites (after Harris et al 1986).

CONCLUSION The evolution of Brasília Belt involved the presence of magmatic arcs, an oceanic crust, and a passive continental margin, in the context of a back-arc basin. It was subjected, on the initial stages, to processes of arc accretion (Pimentel et al. 1999a), and on the later stages, to the collision of different crustal blocks and their final collage. The later stages of the process could reflect the interaction of three major crustal segments: the Amazon, São Francisco and Paraná continents.

The first interaction could be represented by the collision between the Paraná and São Francisco continents. During that collision, matter moved from southwest to northeast (Fig. 7- $M_{/} / \mathrm{D} p$ event) and peraluminous granitic bodies were emplaced into the in Araxá Terrane. In succession, at higher crustal levels, the thrust sheets were imbricated. At this stage, a new collision between these two continents and the Amazon continent initiated, confining matter into a corridor flowing from northwest to southeast, and building Araxá Synform (Fig. 7- $\mathrm{M}_{2} / \mathrm{D}_{2} \mathrm{t}$ event).

The result of the latter interaction between all crustal blocks was the development of wrench sinistral faults that crosscut all stratigraphic terranes (Fig. $7-\mathrm{M}_{3} / \mathrm{D}_{3}$ event). All these processes developed between 630 and $580 \mathrm{Ma}$, during the Brasiliano Orogeny, as part of the final collage of Gondwanaland.

Acknowledgements The first author is grateful to CAPES for its financial support through a doctoral research scholarship and to the Instituto de Geosciências (Universidade de Brasília). To Prof. Marco Antonio Fonseca for his help during field works and for reading the

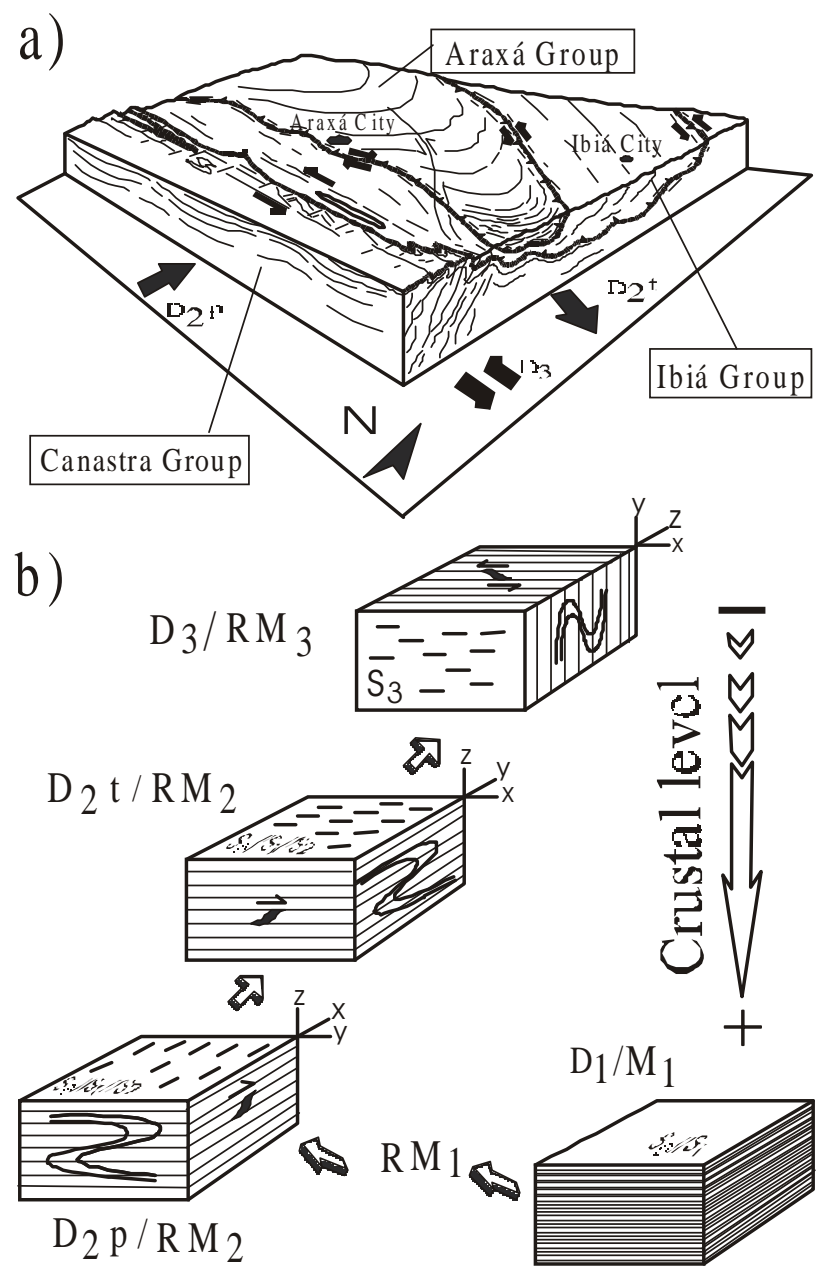

Figure 7 - (a) General picture of the Araxá Synform showing the relationships between Araxá, Ibiá and Canastra Groups and their tectonic contacts. Black arrows represent main kinematic vectors; $(b)$ tectonic and metamorphic evolution (time and crustal level) of the deformation phases and their structures; kinematic indicators on $X Z$ plane; folds hinges on $Y Z$ planes; stretching lineations on $X Y$ plane; foliation is represented by $X Y$ plane (Seer 1999).

manuscript, to Amandina Morbeck for reviewing the English and to two anonymous referees of RBG for the critical review of the manuscript.

\section{References}

Barbosa O., Braun O.P.G., Dyer R.C., Cunha C.A.B.R. 1970. Geologia da região do Triângulo Mineiro. DNPM/DFPM. (Boletim 136) 140p.

Brod J.A. 1999. Petrology and geochemistry of the Tapira Alcaline Complex, Minas Gerais State, Brazil. (PhD Thesis, University of Durham) England. 486p.

Condie K.C. 1989. Plate tectonics and crustal evolution. Pergamon Press. 476p.

Ferrari PG 1989. A Formação Ibiá e sua pertinência ao Grupo Araxá. In : Simp. Geol. P.G. 1989. A Formação Ibiá e sua pertinencia ao Grupo Araxá. In: Simp. Geol.

Minas Gerais, 5, Belo Horizonte, 1989. Anais....Belo Horizonte, SBG, p. 257-261. magmatism. In: Coward M.P \& Ries, A.C. (eds) 1986 . Collision Teton-zone magmatism. In: Coward, M.P. \& Ries, A.C. (eds) 1986. Collision Tectonics. Geological Society Special Publication, 19: 67-81. Blacwell Scientific Publications. Oxford.

Henderson P. 1984. Rare-earth element geochemistry. Elsevier. Amsterdan. 510p.

Howell D.G. 1993. Tectonics of suspect terranes - mountain building and continental growth. Topics in the Earth Sciences 3. Chapman \& Hall. London, 231p.

Paulsen S., Bosum W., Hagen D., Lacerda G.M., Lima J.E.S., Ribeiro C.L., Godoy A., Souza A.A., Bicalho F.D., Ferrari P.G., Heineck C., Steiner H.P., Paulino J., Richter P., Lahner L., Mollat H., Resch M., Ostwald J., Jochmann D. 1974 Relatório de reconhecimento geológico-geoquímico Pratinha-Argenita-Tapira-Serra da Canastra,
Minas Gerais. Convênio Geofísico Brasil-Alemanha. CPRM/DNPM/Serviço Geológico da República Federal da Alemanha. 57p.

Pimentel M.M., Fuck R.A., Botelho N.F. 1999 a. Granites and the geodynamic history of the neoproterozoic Brasilia Belt, Central Brazil: a review. Lithos, 46:1-21.

Pimentel M.M., Dardenne M.A., Viana M.G., Gioia S.M.C.L., Seer H.J. 1999b. Nd isotopes and the provenance of sediments of the Brasília Belt, Central Brasil. In: Simp. SulAmericano Geol. Isotop., 2. Actas...Cordoba, p. 426-429.

Price R.C., Johnson L.E., Crawford A.J. 1990. Basalts of the North Fiji Basin: the generation of back-arc basin magmas by mixing of depleted and enriched mantle sources. Contr Mineral. Petrol., 105:106-121.

Seer H. J. 1999. Evolução tectônica dos Grupos Araxá, Ibiá e Canastra na Sinforma de Araxá, Araxá, Minas Gerais. (PhD Thesis - Universidade de Brasilia) Brasília. 267p. Simões L.S.A. \& Navarro G. 1996. Estruturação da Faixa Brasília na região de Araxá, MG. In: Congr. Bras. Geol., 39, Salvador, 1996. Anais...Salvador, SBG, p 92-95.

Contribution IGC-102

Received March 1, 2000 Accepted for publication May 10, 2000 